\title{
Subtype Distribution of Blastocystis in Pregnant Women and Analysis of Possible Risk Factors
}

\author{
Gebelerde Blastocystis Alt Tiplerinin Araşturlmast ve Potansiyel Risk \\ Faktörlerinin Değerlendirilmesi
}

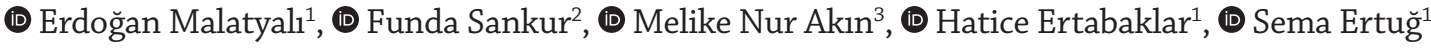 \\ ${ }^{1}$ Aydın Adnan Menderes University Faculty of Medicine, Department of Parasitology, Aydın, Turkey \\ ${ }^{2}$ Muğla Sitkı Koçman University, Training and Research Hospital, Microbiology Laboratory, Muğla, Turkey \\ ${ }^{3}$ Muğla Sıtkı Koçman University, Training and Research Hospital, Clinic of Obstetrics and Gynaecology, Muğla, \\ Turkey
}

Cite this article as: Malatyalı E, Sankur F, Akın MN, Ertabaklar H, Ertuğ S. Subtype Distribution of Blastocystis in Pregnant

Women and Analysis of Possible Risk Factors. Turkiye Parazitol Derg 2020;44(4):221-5.

\begin{abstract}
Objective: Since the identification of Blastocystis subtypes (ST) in the last decade, much has been learned about the genetic diversity of Blastocystis isolates in different populations, except pregnant women. The objective of this study is to investigate the genetic diversity of Blastocystis in pregnant women and analyse some demographic factors.

Methods: The faecal samples from 100 pregnant women were collected at an Obstetrics and Gynecology Department in Muğla, Turkey. Thereafter, Blastocystis positivity was detected by direct microscopy and culture. The positive cultures were subjected to DNA isolation, and the Blastocystis barcode region was amplified with polymerase chain reaction. Next, the sequences were queried against GenBank nucleotide and Blastocystis STs (18S) databases.

Results: Blastocystis was detected in $14 \%$ (14 out of 100) of the faecal samples by culture and $10 \%$ (10 out of 100) of the samples by direct microscopy. Nine of Blastocystis isolates (64.4\%) were ST3, three (21.4\%) were ST1 and two (14.2\%) were ST2. Neither the demographic features nor the gastrointestinal symptoms were statistically related to Blastocystis infection.

Conclusion: The findings in this study agreed with the most of the previous human studies that found ST3 as the most abundant genotype. This study reported the frequency of Blastocystis in pregnant women and highlighted the importance of comprehensive studies with more cases of Blastocystis during pregnancy.
\end{abstract}

Keywords: Blastocystis, pregnancy, subtypes, symptoms

Öz

Amaç: Blastocystis alt tiplerinin (ST) yakın tarihte tanımlanmasından bu yana, farklı popülasyonlarda Blastocystis izolatlarının genetik çeşitliliği hakkında yeni bilgiler elde edilmiştir. Bu çalışmada, gebe kadınlarda Blastocystis'nin genetik çeşitliliğinin araştırması ve bazı demografik faktörlerin değerlendirilmesi amaçlanmıştır.

Yöntemler: Çalışma kapsamında, Muğla Kadın Hastalıkları ve Doğum Bölümü’nden toplam 100 hamile kadından toplanan dışkı örnekleri incelenmiştir. Blastocystis pozitifliği, direkt mikroskopi ve kültür ile tespit edilmiştir. Pozitif kültürlerden DNA izolasyonu yapılmış ve Blastocystis genomunda barkod bölgesi polimeraz zincir reaksiyonu ile amplifiye edilmiştir. Elde edilen diziler, Genbank ve Blastocystis alt tür (18S) veri tabanlarına girilerek alt tipler belirlenmiştir.

Bulgular: Kültür yöntemi ile 14 dışkı örneğinde (\%14), direkt mikroskopi yöntemiyle ise 10 örnekte (\%10) Blastocystis saptanmıştır. Blastocystis izolatlarının dokuzu $(\% 64,4)$ ST3, üçü $(\% 21,4)$ ST1 ve ikisi $(\% 14,2)$ ST2 alt tipi olarak tanımlanmıştır. Demografik özellikler ve gastrointestinal semptomlar değerlendirildiğinde, herhangi biri Blastocystis enfeksiyonu ile istatistiksel olarak ilişkili bulunmamıştır.

Sonuç: Bu çalışmada ST3’ün en yaygın genotip olarak bulunması, önceki çalışmaların birçoğu ile uyumlu görülmektedir. Ayrıca, çalışmamız gebelerde Blastocystis görülme sıklığını ortaya koymakta ve bu konuda örnek sayısının fazla olduğu kapsamlı çalışmalara ihtiyaç duyulmaktadır.

Anahtar kelimeler: Blastocystis, hamilelik, alt tip, semptomlar

Received/Geliş Tarihi: 09.10.2019 Accepted/Kabul Tarihi: 18.08.2020

Address for Correspondence/Yazar Adresi: Funda Sankur, Muğla Sıtkı Koçman University, Training and Research Hospital, Microbiology

Laboratory, Muğla, Turkey

Phone/Tel: +90252 2141326 E-mail/E-Posta: fundasankur@yahoo.com.tr ORCID ID: orcid.org/0000-0001-6409-7268

(C) Copyright 2020 Turkish Society for Parasitology - Available online at www.turkiyeparazitolderg.org

(C) Telif hakkı 2020 Türkiye Parazitoloji Derneği - Makale metnine www.turkiyeparazitolderg.org web sayfasından ulașılabilir. 


\section{INTRODUCTION}

Blastocystis is a highly prevalent enteric protozoon in humans and a variety of animals (1). Despite of the controversy about Blastocystis pathogenicity, recent researches has revealed that it may be considered as an opportunistic pathogen in immunocompromised cases (2). Even though there is not a complete immunosuppression, pregnancy is a period with immunomodulation of mother (3). Additionally, iron deficiency anaemia (IDA), protein, zinc, folate deficiency may develop due to the impairment of absorption caused by intestinal parasitic infections in pregnancy. These deficiencies may result in some fatal consequences: increased perinatal mortality rates, low birth weight and intrauterine tension. It was reported that pregnant women infected with Entamoeba histolytica were more susceptible to penetration of intestinal mucosa and the infection increased the risk of preterm delivery two fold (4). Heavy infection with Schistosoma mansoni increased risk of anemia in a cross-sectional survey in Tanzania (5). Soil transmitted helmint infections including Ascaris lumbricoides, Trichuris trichiura and hookworms were soil transmitted helminth infections were significantly associated with anemia in pregnant women (6).

The complex, collective and highly active population of living microorganisms in gastrointestinal tract of humans is defined as gut microbiota and it exerts a marked influence on the host both in homeostasis and diseases. A number of host-related and environmental factors contribute to the formation and change of microbiota from infancy to adolescence. Gut microbiota establish some dramatic changes during pregnancy, primarily as a result of increased energy requirements of the developing foetus. Additionally, recent evidence suggests that the colonisation and immune system of foetus is highly influenced by maternal gut microbiota (7). The position and role of Blastocystis in gut microbiota is a growing area of interest, some authors have asserted that it can be an indicator of a healthy gut microbiota (8). The genetic heterogeneity of Blastocystis became a major area of interest, recently. Blastocystis isolates have been classified into 17 different genotypes/or subtypes, with small subunit ribosomal RNA (SSU rRNA) gene sequence analysis. The nine of them were isolated from human faecal samples; ST3 is the predominant subtype which is also known as human subtype (9). Subtype distribution of Blastocystis was investigated in a variety of study groups and some factors factors have been found to be related to the Blastocystis infection. However, to the best of our knowledge, no previous study has investigated Blastocystis subtypes during pregnancy. The aims of this study were to determine the genetic diversity of Blastocystis in pregnant women and also analyse gastrointestinal symptoms and demographic factors for Blastocystis infection.

\section{METHODS}

\section{Samples}

Faecal samples were collected from 100 pregnant women who admitted to Muğla Sitkı Kocman University, Training and Research Hospital, Clinic of Obstetrics and Gynaecology inbetween November 2014 and April 2015. A semi-constructed questionnaire was used to collect data which included the demographic characteristics: residence, livestock farming, having pet animal, drinking water supply, home ownership, occupation and monthly income. The presence of common gastrointestinal symptoms (abdominal pain, diarrhoea, constipation, flatulence, urticaria and lack of appetite) was also asked to the women in the questionnaire. A single faecal sample was taken from each woman and brought to the laboratory with a plastic container without fixatives.

The study was approved by Muğla Sıtkı Koçman University Clinical Research Ethics Committee (07.11.2014). The informed consents were obtained from pregnant women in the present study.

\section{Direct Microscopy, Culture and Polymerase Chain Reaction}

All samples were examined with both direct microscopy and Jones medium for the presence of Blastocystis forms. Positive cultures were centrifuged at 12,000 $\mathrm{g}$ for one minute and pellets were used for DNA isolation with a commercial kit (DNAzol, Invitrogen). The barcode region was amplified with a set of conserved polymerase chain reaction primers ( $\mathrm{RD} 5$ and $\mathrm{BhRDr}$ ) for the analysis of approximately $600 \mathrm{bp}$ of SSU rRNA coding gene (10). The reaction was set in $30 \mu \mathrm{L}$ volume: $1-2 \mu \mathrm{L}$ of template DNA, $0.3 \mathrm{U}$ of Taq DNA polymerase, $0.2 \mathrm{mM}$ of each dNTP, $0.4 \mathrm{pmol}$ of each of the primers and $1 \times$ Taq buffer with $\left(\mathrm{NH}_{4}\right)_{2} \mathrm{SO}_{4}$. The amplicons were purified and sequenced by a commercial facility with 377 DNA Sequencer (Applied Biosystems).

\section{Determination of Subtypes and Phylogenetic Analysis}

The barcode sequences of isolates were queried against both Genbank and Blastocystis Subtype (18S) databases. Sequences were aligned with references by using ClustalW algorithm in Molecular Evolutionary Genetics Analysis version 6.0 (MEGA) and a phylogenetic tree was constructed with the NeighborJoining method in 1.000 replicates bootstrap test. Additionally, the evolutionary distances of sequences were calculated with the maximum composite likelihood (11-13).

\section{Statistical Analyses}

The study did not have defined exclusion criteria. All of the pregnant women who volunteered to participate were included in the study. The qualitative variables including residence, livestock farming, having pet animal, drinking water supply, home ownership, occupation and monthly income were analysed with chi-square test in Statistical Package for Social Sciences (SPSS 19.0) software. The analysis of gastrointestinal symptoms (abdominal pain, diarrhoea, constipation, flatulence, urticaria and lack of appetite) was also performed in the same way. The significance level was set at $\alpha=0.05$.

\section{RESULTS}

The mean age of pregnant women was $27.4 \pm 5.3$ and the ages were varying from 16 to 44. Blastocystis was found in 14 of 100 (14\%) pregnant women by culture; however, the rate was $8 \%$ by direct microscopy. The subtype distribution of isolates were as follows: ST3 nine isolates (64.4\%), ST1 three isolates (21.4\%) and ST2 two isolates (14.2\%) (Figure 1). Blastocystis SSU rRNA gene partial sequences were deposited to Genbank with accession numbers: MH349731, MH349744 and MH349753. 
Among the Blastocystis positive 14 cases, the most common gastrointestinal symptom was flatulence $57.1 \%(n=8)$, followed by abdominal pain $(n=6,42.5 \%)$ and constipation $(n=4,28.5 \%)$.

Blastocystis negative pregnant women $(\mathrm{n}=86)$ were defined as control group and compared to Blastocystis positive pregnant women $(n=14)$. Statistical analysis of demographic factors and symptoms with the presence of Blastocystis was presented in
Table 1 . None of these factors were statistically related with Blastocystis positivity.

Additionally, the comparison Blastocystis positivity according to the presence and absence of symptoms was given in Table 2. It was found that Blastocystis positivity was not statistically different between the cases with and without symptoms.

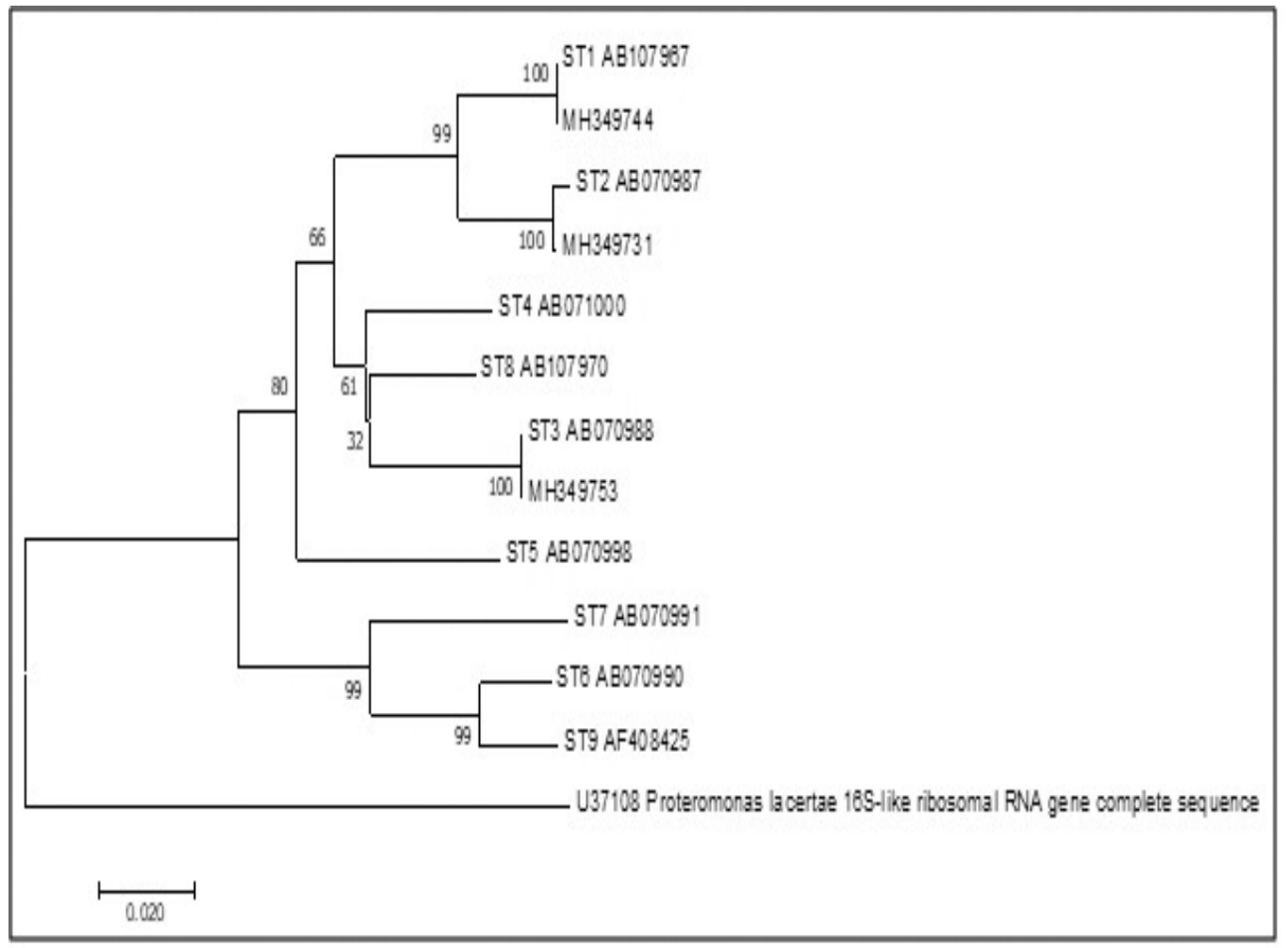

Figure 1. Evolutionary distances of Blastocystis isolates according to barcode region (Genbank accession numbers: U37108: outgroup; MH349731, MH349744 and MH349753: sequences from this study; STs are reference sequences)

Table 1. Descriptive and statistical analysis of possible Blastocystis related factors

\begin{tabular}{|c|c|c|c|c|c|c|}
\hline & & \multicolumn{2}{|l|}{ Blastocystis } & \multirow[b]{2}{*}{ Total } & \multirow[b]{2}{*}{$x^{2}$} & \multirow[b]{2}{*}{$\mathbf{p}$} \\
\hline & & Positive (\%) & Control (\%) & & & \\
\hline Residence & Urban & $6(42.9)$ & $8(57.1)$ & 14 & 0.09 & 0.581 \\
\hline \multirow[t]{2}{*}{ Livestock farming } & Yes & $6(43)$ & $8(57.1)$ & 14 & 0.05 & 0.583 \\
\hline & No & $36(42.9)$ & $50(58.1)$ & 86 & - & - \\
\hline Having pet animal & No & 25 (29.1) & $61(70.9)$ & 86 & & \\
\hline \multirow[t]{2}{*}{$\begin{array}{l}\text { Drinking } \\
\text { water supply }\end{array}$} & Tap water & $4(28.6)$ & $10(71.4)$ & 14 & 1.383 & 0.189 \\
\hline & Bottled & $39(45.3)$ & $47(54.7)$ & 86 & - & - \\
\hline Home ownership & Owner & $5(35.7)$ & $9(64.4)$ & 14 & 1.329 & 0.388 \\
\hline \multirow{2}{*}{$\begin{array}{l}\text { Monthly income } \\
\text { of family }\end{array}$} & Low $(<500 \$)$ & $5(35.7)$ & $9(66.3)$ & 14 & 0.188 & 0.774 \\
\hline & $\operatorname{High}(\geq 500 \$)$ & $36(41.9)$ & $50(58.1)$ & 86 & - & - \\
\hline
\end{tabular}


Table 2. Blastocystis positivity and presence of symptoms ${ }^{a}$

\begin{tabular}{|c|c|c|c|c|}
\hline Symptoms & Blastocystis $+\mathbf{n}^{\mathrm{b}}(\%)$ & Control nc (\%) & $x^{2}$ & $\mathbf{p}$ \\
\hline Abdominal pain & $3(13)$ & $11(14.3)$ & 0.023 & 0.880 \\
\hline Diarrhoea & $1(11.1)$ & $13(14.2)$ & 1.610 & 0.204 \\
\hline Constipation & $4(16.7)$ & $10(13.2)$ & 0.187 & 0.666 \\
\hline Flatulence & $5(20.8)$ & $9(11.8)$ & 1.225 & 0.268 \\
\hline Urticaria & $2(11.1)$ & $12(14.6)$ & 0.152 & 0.696 \\
\hline Lack of appetite & $3(13.6)$ & $11(14.1)$ & 0.03 & 0.956 \\
\hline
\end{tabular}

\section{DISCUSSION}

Blastocystis is one of the most common protozoa in human faecal samples. Despite the recent development in the understanding of Blastocystis genetic diversity and symptomatology, the role of Blastocystis infection during pregnancy is not a well-studied area. The present study was designed to investigate Blastocystis frequency and subtype distribution in pregnant women. The Blastocystis frequency was $14 \%$ in our study, there were limited number of studies in the literature that investigated Blastocystis in pregnant women. It was reported that Blastocystis infection contributed to the development of IDA during pregnancy. They found that Blastocystis frequency was significantly higher in IDA patients (40\%) than non-anemic pregnant controls $(6.3 \%)$. Additionally, the overall frequency was $26.5 \%$ among all studied subjects (14). Another study investigated intestinal parasitism among pregnant women who lived in low socio economic residential areas in Bogotá, they reported that Blastocystis spp. frequency was $25 \%$ (15). Our study investigated the subtype distribution of Blastocystis in a pregnant population for the first time in the literature. As pathogenicity has been a controversial and much disputed area in Blastocystis researches, a variety of study populations such as cancer, ulcerative colitis, and Irritable Bowel syndrome patients were subjected in similar studies (1618). Our findings were in accordance with the reported Blastocystis subtype distribution in these studies, all have found Blastocystis ST3 as the predominant genotype.

There were a few studies that investigated the frequency of Blastocystis in Muğla and surrounding cities. The city is located in the south-western of Turkey and the centrum is about $30 \mathrm{~km}$ from the seacoast in the Gulf of Gokova. It was reported that $7.4 \%$ of school aged children were infected with Blastocystis in Mugla (19). In addition, subtype distribution was found as follows: ST3 (34.2\%), ST1 (31.4), ST2 (25.7) and ST7 (2.8\%). In a study, Blastocystis subtypes from the culture positive 61 samples were investigated. They found a comparable result in that study: ST3 (38.6\%), ST2 (29.5\%), ST1 (20.5\%), ST1+ST3 (9.1\%), and ST1+ST2 (2.3\%) (20). Moreover, a study reported that most common Blastocystis subtype was ST3 with a frequency of 52.6, followed by ST2 (22.1\%), ST1 (17.9\%), ST7 (4.2\%), ST2+ST3 (2.1\%) and ST1+ST3 (1.1\%) in Aydin (21). In the present study we detected three different subtypes (ST1, 2, and 3) that is comparable to the other studies.

In the present study we have compared Blastocystis frequency with respect to residence, livestock farming, having pet animal, drinking water supply, home ownership, occupation and income. None of these parameters were significantly related with Blastocystis presence. In the literature some have reported that Blastocystis infection has been related to the consumption of untreated water, close contact with animals, intra-family infections and mother's education (22-24).

In the present study, none of the gastrointestinal symptoms were found to be related with presence of Blastocystis. Flatulence, abdominal pain and constipation were the most common clinical findings in Blastocystis infected pregnant women. Blastocystis infections are highly asymptomatic and gastrointestinal symptoms are seen in a small proportion of infected cases (25). It has also been suggested that Blastocystis may be a marker of a healthy intestinal flora (26). However, in a number of studies, non-specific gastrointestinal symptoms such as diarrhea, abdominal pain and bloating, as well as dermatological symptoms have been linked to Blastocystis infection (27). In addition a study reported that fever was common in symptomatic Blastocystis infected individuals (28). The main limitation of such studies, however, was the lack of elimination of other possible factors such as pathogens, underlying diseases and immune status of cases. In brief, the current data are rather controversial, and there is no general agreement about clinical importance of Blastocystis infection. However, recently Blastocystis pathogenesis is reasonable thought to be a multi-factor phenomenon that is highly depended on both Blastocystis and host related factors (29).

\section{CONCLUSION}

Although the current study was based on relatively small number of participants, it highlighted the importance of Blastocystis in pregnancy because of the high infection rate. Therefore, parasitological examinations are recommended in gynaecological clinics. Further studies regarding the role of Blastocystis in extended series of pregnant women would be worthwhile.

\section{* Ethics}

Ethics Committee Approval: The study was approved by Muğla Sitkı Koçman University Clinical Research Ethics Committee (07.11.2014).

Informed Consent: The informed consents were obtained from pregnant women in the present study.

Peer-review: Internally peer-reviewed. 


\section{* Authorship Contributions}

Concept: E.M., F.S., H.E., Design: E.M., F.S., M.N.A., S.E., Data Collection or Processing: E.M., F.S., M.N.A., Analysis or Interpretation: E.M., F.S., M.N.A., H.E., Literature Search: E.M., S.E., Writing: E.M., H.E.

Conflict of Interest: The authors confirm that this article content has no conflict of interest.

Financial Disclosure: The authors declared that this study received no financial support.

\section{REFERENCES}

1. Noel C, Dufernez F, Gerbod D, Edgcomb VP, Delgado-Viscogliosi P, Ho LC, et al. Molecular phylogenies of Blastocystis isolates from different hosts: implications for genetic diversity, identification of species, and zoonosis. J Clin Microbiol 2005; 43: 348-55.

2. Wawrzyniak I, Poirier P, Viscogliosi E, Dionigia M, Texier C, Delbac F, et al Blastocystis, an unrecognized parasite: an overview of pathogenesis and diagnosis. Ther Adv Infect Dis 2013; 1: 167-78.

3. Mor G, Cardenas I. The immune system in pregnancy: A unique complexity. Am J Reprod Immunol 2010; 63: 425-33.

4. Mahande AM, Mahande MJ. Prevalence of parasitic infections and associations with pregnancy complications and outcomes in northern Tanzania: A registry-based cross sectional study. BMC Inf Dis 2016; 16: 78.

5. Ajanga A, Lwambo NJS, Blair L, Nyandindi U, Fenwick A, Brooker S. Schistosoma mansoni in pregnancy and associations with anaemia in northwest Tanzania. Trans R Soc Trop Med Hyg 2006; 100: 59-63.

6. Getachew M, Yewhalaw D, Tafess K, Getachew Y, Zeynudin A. Anaemia and associated risk factors among pregnant women in Gilgel Gibe dam area, Southwest Ethiopia. Parasites Vectors 2012; 5: 296.

7. Chung SY, Ravel J, Regan M. Clinical relevance of gastrointestinal microbiota during pregnancy: a primer for nurses. Biol Res Nurs 2018; 20: 84-102.

8. Forsell J, Bengtsson-Palme J, Angelin M, Johansson A, Evengård B, Granlund M. The relation between Blastocystis and the intestinal microbiota in Swedish travellers. BMC Microbiol 2017; 17: 231.

9. Alfellani MA, Stensvold CR, Vidal-Lapiedra A, Onuoha ES, FagbenroBeyioku AF, Clark CG. Variable geographic distribution of Blastocystis subtypes and its potential implications. Acta Trop 2013; 126: 11-8.

10. Scicluna SM, Tawari B, Clark CG. DNA barcoding of Blastocystis. Protist 2006; 157: 77-85

11. Saitou N, Nei M. The neighbor-joining method: a new method for reconstructing phylogenetic trees. Mol Biol Evol 1987; 4: 406-25.

12. Tamura K, Nei M, Kumar S. Prospects for inferring very large phylogenies by using the neighbor-joining method. Proc Natl Acad Sci USA 2004; 101: 11030-5.

13. Tamura K, Stecher G, Peterson D, Filipski A, Kumar S. MEGA6: Molecular Evolutionary Genetics Analysis version 6.0. Mol Biol Evol 2013; 30: 27259.

14. El Deeb HK, Salah-Eldin H, Khodeer S. Blastocystis hominis as a contributing risk factor for development of iron deficiency anemia in pregnant women. Parasitol Res 2012; 110: 2167-74.
15. Espinosa Aranzales AF, Radon K, Froeschl G, Pinzón Rondón ÁM, Delius M. Prevalence and risk factors for intestinal parasitic infections in pregnant women residing in three districts of Bogotá, Colombia. BMC Public Health 2018; 18: 1071.

16. Coskun A, Malatyali E, Ertabaklar H, Yasar MB, Karaoglu AO, Ertug S. Blastocystis in ulcerative colitis patients: Genetic diversity and analysis of laboratory findings. Asian Pac J Trop Med 2016; 9: 916-9.

17. Yersal O, Malatyali E, Ertabaklar H, Oktay E, Barutca S, Ertug S. Blastocystis subtypes in cancer patients: Analysis of possible risk factors and clinical characteristics. Parasitol Int 2016; 65: 792-6.

18. Doğruman-Al F, Kuştimur S, Yoshikawa H, Tuncer C, Şimşek Z, Tanyüksel M, et al. Blastocystis subtypes in irritable bowel syndrome and inflammatory bowel disease in Ankara, Turkey. Mem Inst Oswaldo Cruz 2009; 104: 724-7.

19. Sankur F, Ayturan S, Malatyali E, Ertabaklar H, Ertug S. The Distribution of Blastocystis subtypes among school-aged children in Mugla, Turkey. Iran J Parasitol 2017; 12: 580-6.

20. Ertuğ S, Malatyalı E, Ertabaklar H, Özlem Çalışkan S, Bozdoğan B. Subtype distribution of Blastocystis isolates and evaluation of clinical symptoms detected in Aydin province, Turkey. Mikrobiyol Bul 2015; 49: 98-104.

21. Malatyalı E, Ertabaklar H, Ertuğ S. DNA Barkotlama Yöntemiyle Blastocystis Alt Tiplerinin Belirlenmesi ve Tanı Yöntemlerinin Değerlendirilmesi. Mikrobiyol Bul 2019; 53: 308-18.

22. Abdulsalam AM, Ithoi I, Al-Mekhlafi HM, Ahmed A, Surin J, Mak JW. Drinking water is a significant predictor of Blastocystis infection among rural Malaysian primary school children. Parasitology 2012; 139: 101420.

23. Osman M, Bories J, El Safadi D, Poirel MT, Gantois N, BenamrouzVanneste $S$, et al. Prevalence and genetic diversity of the intestinal parasites Blastocystis sp. and Cryptosporidium spp. in household dogs in France and evaluation of zoonotic transmission risk. Vet Parasitol 2015; 214: 167-70.

24. Ajjampur SS, Png CW, Chia WN, Zhang Y, Tan KS. Ex vivo and in vivo mice models to study Blastocystis spp. adhesion, colonization and pathology: closer to proving koch's postulates. PLoS One 2016; 11: e0160458.

25. Mingmongkol S, Prasartpan S, Aumkhayan S, Watthanakulpanich D. Asymptomatic Blastocystis infected persons as potential carriers of disease in Thailand. Int J Trop Dis Health 2015; 10: 1-10.

26. Scanlan PD, Stensvold CR, Rajilic-Stojanovic M, Heilig HG, De Vos WM, O'Toole PW, et al. The microbial eukaryote Blastocystis is a prevalent and diverse member of the healthy human gut microbiota. FEMS Microbiol Ecol 2014; 90: 326-30.

27. Pasqui AL, Savini E, Saletti M, Guzzo C, Puccetti L, Auteri A. Chronic urticaria and Blastocystis hominis infection: a case report. Eur Rev Med Pharmacol Sci 2004; 8: 117-20.

28. Mohammad NA, Al-Mekhlafi HM, Anuar TS. Genetic diversity of Blastocystis isolates from symptomatic and asymptomatic Orang Asli In Pahang, Malaysia. Southeast Asian J Trop Med Public Health 2018; 49: 189-97.

29. Stensvold CR. Blastocystis: Genetic diversity and molecular methods for diagnosis and epidemiology. Trop Parasitol 2013; 3: 26-34. 